Physiological Psychology, 1969,69 633-666.

FREDERICSON, E. Response latency and habit strength in relationship to spontaneous fighting in C57 black mice. Anatomical Record, 1949, 105, 509 (Abstract)

FREDERICSON, E. Aggressiveness in female mice. Journal of Comparative \& Physiological Psychology, 1952, 45. 254-257.

FREDERICSON, E., FINK, C. D., \& PARKER, J. R. Elicitation and inhibition of competitive fighting in food deprived mice. Journal of Genetic Psychology, $1955,86,131,141$.

HALL, C. S. Temperament: A survey of animal studies. Psychological Bulletin, $1941,38,909,943$.

KAH N, M. W. The effect of severe defeat at various age levels on the aggressive behavior of mice. Journal of Genetic Psychology, 1951, 79, 117-130.

MORGRET, M. K. An apparatus for detection and counting of mouse squeals. Behavior Research Methods \& Instrumentation, 1972, 4, 21-23.

RETZLAFF, E. C. Studies in population physiology with albino mice. Biological Genetics, 1938, 14, 238-265.
SCOTT, J. P. Incomplete adjustment caused by frustration of untrained fighting mice. Journal of Comparative \& Physiological Psychology, 1946, 39, 379-390.

SCOTT, J. P. Agonistic behavior of mice and rats: A review. American Zoologist, $1966,6,683-701$

SCOTT, J. P., \& FREDERICSON, E. The causes of fighting in mice and rats. Physiological Zoology, 1951, 24, 273-309.

THOR, D. H., \& HOATS, D. L. Morphine-am phetamine-induced fighting and interim socialization. Psychonomic Science, 1970, 20, 156-158.

THOR, D. H., HOATS, D. L., \& THOR, C. $J$. Morphine induced fighting and prior social experience. Psychonomic Science, $1970,18,137-139$

ULRICH, J. The social hierarchy in albino mice. Journal of Comparative Psychology, 1938, 25, 373, 413.

UTSURIK A WA, N. Temperamental differences betw een outbred and inbred strains of the albino rat. Journal of Animal Behaviour, 1917, 7, 111-120.

YERKES, R. M. The heredity of savageness and wildness in rats. Journal of Animal Behaviour, 1913, 3, 286-296.

\title{
An inexpensive pure-tone pattern generator
}

\author{
MAURICE E. T. SWINNEN and NORMAN A. KRASNEGOR* \\ Walter Reed Army Institute of Research, Washington, D.C. 20012
}

A low-cost sound pattern generator that is remotely programmable has been developed to produce pure-tone auditory patterns. The device, which is compatible with relay programming equipment, can generate either of two auditory patterns in the sequence ABA or BAB. The generator features an independently settable range of $\mathrm{ON}$ and $\mathrm{OFF}$ durations $(0.1$ to $1.0 \mathrm{sec})$ for pure-tone bursts and a selectable range $(0.2$ to $2.0 \mathrm{sec})$ of intercycle intervals. The inexpensive construction cost coupled with the flexibility of the timing characteristics of the generator should make it of interest to a wide variety of auditory researchers.

This report describes a low-cost remotely programmable sound pattern

* Reprints may e obtained from the senior author, Department of Neurophysiology, Division of Neuropsychiatry, Walter Reed Army Institute of Research, Walter Reed Army Medical Cénter, Washington, D.C. 20012. from the pattern generator. The pattern is composed of two frequencies given in either an ABA or a $B A B$ sequence, selectable remotely. The ON times for the $t_{1}, t_{3}$, and $t_{5}$ tone bursts are individually adjustable from 0.1 to $1.0 \mathrm{sec}$. The OFF times, $t_{2}$ and $t_{4}$ are also adjustable within the same range as described above. The intercycle interval, $t_{6}$ was designed to be adjustable from 0.2 to $2.0 \mathrm{sec}$. The two pure tones are generated by two oscillators not included in the pattern generator.

Figure 2 shows a schematic of the circuit design for the device. The individual $O N$ and $O F F$ durations, $t_{1}$ through $t_{6}$ are produced by a closed loop composed of six one-shot multivibrators, labeled OS, through $\mathrm{OS}_{5}$ in the schematic. Commercially available circuit modules (Type EM 5011, Electronic Modules Corp. Timonium, Md.), chosen for their ease of mounting and small size, were incorporated in the device, although any other one-shot multivibrator having identical characteristics (e.g. OS-204 BRS-Foringer, Beltsville, Md.) can be used successfully. The inset in Fig. 2 labeled A shows the connections around the one-shot and gives the values of the $\mathrm{RC}$ network required to provide the necessary dwell times.

The design of the generator employs diode-relay logic throughout its construction. All relays used are ordinary $24 \cdot \mathrm{V}$ types with the exception of those used in conjunction with the switching of pure tones $\left(R_{1}\right.$ and $\mathrm{RD}_{2}$ ). These relays are of the $6 \cdot \mathrm{V}$ variety and have mercury-wetted contacts to insure against switching transients. Relays $R Y_{1}$ and $R Y_{2}$ are spike-suppressed by Diodes $\mathrm{D}_{4}$ and $D_{5}$, respectively. Any diode with a minimum breakdown voltage of $200 \mathrm{~V}$ is satisfactory. The requirements for Diodes $D_{1}, D_{2}$, and $D_{3}$ can be less stringent than those for $D_{4}$ and $D_{5}$. The $C_{1}$, a 50 -microF $50-V$ capacitor provides a time delay for $\mathbf{R Y}$, which helps insure a chatter-free switching of

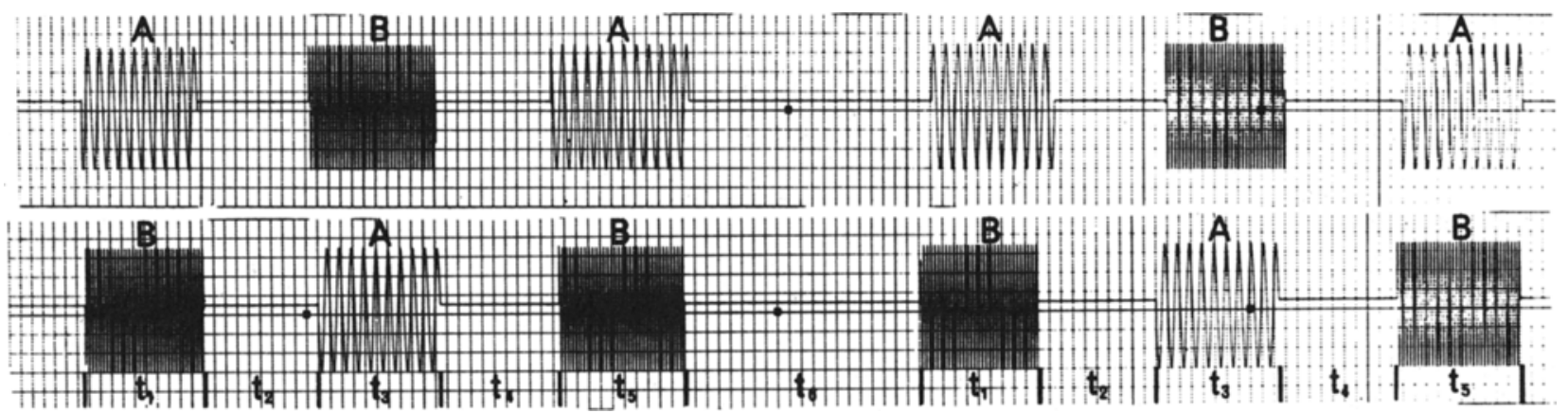

Fig. 1. Typical pattern generator output. The tracing shows Pattern ABA above and Pattern BAB below. In this example, the ON and OFF durations are $1 \mathrm{sec}$ in length; intercycle interval duration is 2 sec. 


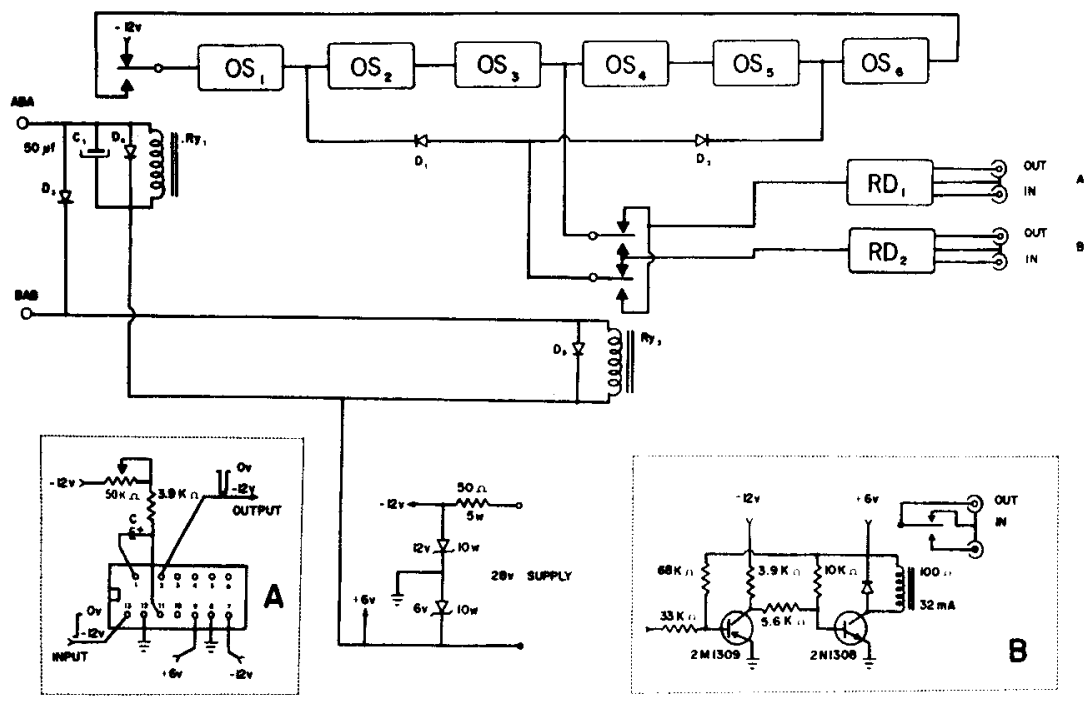

Fig. 2. Circuit diagram for the pattern generator. The values of the capacitors used to obtain the range of values for the ON and OFF durations $(0.1-1.0 \mathrm{sec})$ and the intercycle interval durations $(0.2-2.0 \mathrm{sec})$ are 25 and $50 \mathrm{micro} F$, respectively.

that relay, especially when the triggering of the generator is done with a pushbutton.

Relay Drivers $R_{1}$ and $\mathbf{R D}_{2}$ incorporate the final tone-switching relays. For the sake of economy and compactness of construction, we designed our own relay drivers; however, commercially available modules or cards (e.g., RY-205 BRS-Foringer, Beltsville, Md.) can just as readily be used with success. The opposite pattern is initiated by applying $-28 \mathrm{~V}$ to the BAB stud, both Relays $R Y_{1}$ and $R Y_{2}$ are energized, $R Y_{1}$ through Diode $D_{3}$ and $R Y_{2}$ directly. No matter which pattern is generated, the proper sequencing of tone bursts is provided by the relay drivers which receive inputs from the one-shot multivibrators, $\mathrm{OS}_{1}, \mathrm{OS}_{3}$, and $\mathrm{OS}_{5}$ through Diodes $\mathrm{D}_{1}$ and $\mathrm{D}_{2}$ and the contacts of Relay $\mathrm{RY}_{2}$.

To provide for the necessary -12 and $+6 \mathrm{~V}$ used in the one shot multivibrators and the relay drivers, the $28-\mathrm{V}$ relay rack supply is split by means of a $50-0 h m 5-W$ resistor and a 6- and a 12-V 10-W Zener diode. These three components are mounted, electrically, but not thermally, insulated, on a heat sink.

Total components cost is approximately $\$ 90$.

\section{REFERENCES}

APELLS, J. T., \& GEELS, B. H. Handbook of relay switching technique. New York: Springer-Verlag, 1966.

KRASNEGOR, $N$, A. The effects of telencephalic lesions on auditory discriminations in pigeons. Dissertation Abstracts International, 1971, 31, 5029B.

\section{NOTE}

1. In conducting the rese arch described in this report, the investigators adhered to the "Guide for Laboratory Animal Facilities and Care" as promulgated by the Committee on the Guide for Laboratory Animal Facilities and Care of the Institute of Laboratory Animal Resources, National Academy of Sciences-National Research Council. 